\title{
Diversity of Ordo Lepidoptera In Mangkok Resort, Sebangau National Park, Central Kalimantan
}

\author{
Achmad Faqih Sha'ab ${ }^{1}$ and RC Hidayat Soesilohadi \\ ${ }^{1}$ Laboratory of Entomology, Faculty of Biology, Universitas Gadjah Mada, Indonesia \\ ${ }^{2}$ Laboratory of Ecology and Biology Conservation, Faculty of Biology, Universitas Gadjah \\ Mada, Indonesia
}

\section{Abstract}

The diversity of the butterfly in Sebangau National Park, particularly in the Mangkok Resort area has different morphological features in each species. The differences distinguish each species between families. Steps to know the diversity species or populations can be measured and identified based on similarities or differences in Shannon-Wiener's diversity analysis. This research was conducted by random purposive sampling using insect net and food trap. Observation and sampling were conducted in the area of natural forest and forest restoration during the dry and rainy seasons. The results showed, the species obtained and identified as many as 25 species from 4 families namely Papilionidae, Nymphalidae, Pieridae and Lycaenidae. Butterflies obtained from food trap are 24 individuals from 5 species. The level of diversity, evenness and richness of the species of butterflies in each region during the rainy and dry seasons which are the location of the study

Article History

Received 27 August 2018

Accepted 25 December 2018

Keyword

Diversity

Butterfly

Mangkok Resort are included in the "medium" category with the average value of the diversity index, the evenness and the richness of the butterfly species of 2.502. The relative dominance and relative abundance of the butterfly species in the Mangkok resort shows no species communities that are extreme dominant from species other.

\section{Introduction}

Kalimantan is home to some of the most complex and diverse ecosystems of forests (Myers et al., 2000; Sodhi et al., 2004). The rate of loss of peatland and degradation in Kalimantan is also very high, as a result of selective logging, fires, and conversion to plantations (Harrison et al., 2009). Change of one of environmental factor, such as vegetation, will have an impact on the diversity of the insects, especially the butterfly. According to Patton, (1963), species of host plants and butterfly larvae feed is different between species of butterflies, because the butterfly needs nutritional content that suitable for the development of the larvae. 
Cleary et al, (2006) stated that, about 1,000 species of butterflies had been documented in Kalimantan, with 98 of them in Sebangau National Park. Houlihan et al, (2013) say, to date, as many as 48 species have been recorded in the Sebangau forest. The list includes 27 species that are interested in fermenting fruit and can be monitored using a fruit trap.

Houlihan et al., (2013) say, to date, as many as 48 species had been documented in the forests of National Park Sebangau. The diversity of the butterflies in National Park Sebangau, especially in the Mangkok resorts certainly has different morphological features in each species. Differences in the morphology characteristics of each species of course differentiate between the Familiy. Steps to know the kinship relationships between species or populations can be measured based on the similarity of characters and kinship analysis can be done in various ways, including through the phenetic approach done through grouping based on the similarity of character (Terry, 2000).

The research conducted at Mangkok Resort, Sebangau National Park, is the first step as the first research to obtain data about the diversity of the butterflies, because the information and data of the butterflies species located in the Mangkok Resort was not yet available and considering Resort Mangkok is also a field research area (Field Station), so that research needs to be done both in terms of diversity and kinship relationships of butterflies between species.

\section{Materials and Methods}

\section{Experimental Location}

This study was conducted in June 2017 until March 2018. The study was conducted in the Mangkok Resort area of Sebangau National Park in Central Kalimantan and is at the Coordinating point $114^{\circ} 01^{\prime} 11.25^{\prime \prime} \mathrm{SL}-2^{0} 24^{\prime} 11.25^{\prime \prime} \mathrm{EL}$.

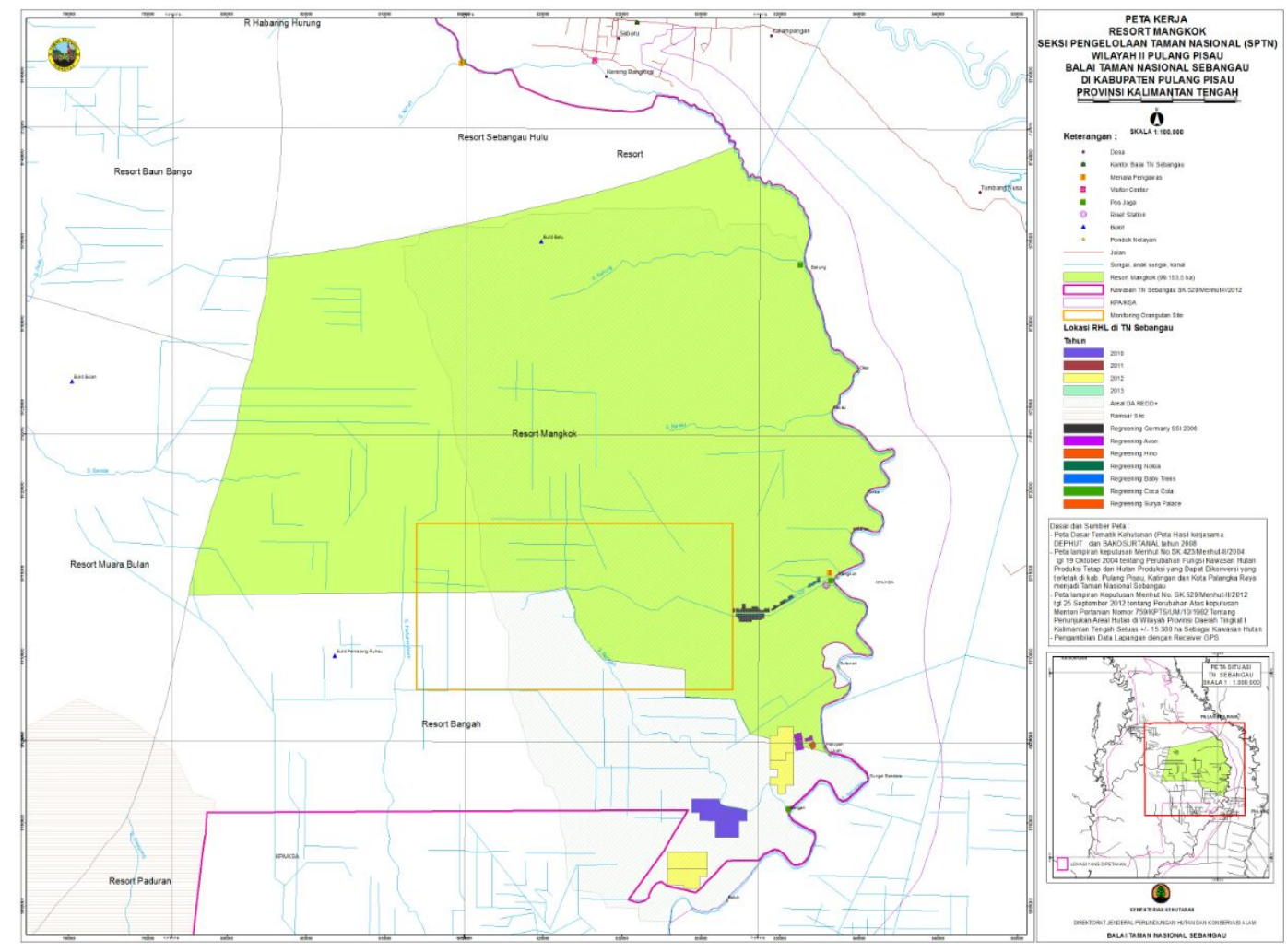

Figure 1. Mangkok Resort Map 


\section{Data Collection}

The survey sampling of butterflies was by random sampling purposive sampling. Data collected in the study were species data and number of individual butterfly obtained in the field during the study. Habitat characteristics data include a biotic component derived from the relative temperature and humidity level data. While the biotic components in this study only inventory vegetation that is suspected of feed, shelter and cover of butterflies.

\section{Data Analysis}

Shanon-Winner Diversity Index (Maguran, 1988): $\mathrm{H}^{\prime}=-\sum(P i \ln P i) P i=\frac{n_{i}}{N}$

Evenness Index (Maguran et al., 2011): $E=\frac{H^{\prime}}{\operatorname{LnS}}$

Type Richness Index (Margalef, 1958): $\mathrm{R}=\frac{S-1}{\operatorname{Ln}(N)}$

Relative Abundance Index (Helvoort, 1981): $(\mathrm{KR})=\frac{\sum \mathrm{ni}}{\sum \mathrm{N}} \times 100 \%$

Domination Index (Odum, 1971): $\mathrm{D}=\Sigma(\mathrm{ni} / \mathrm{N})^{2}$

\section{Results and Discussion}

The results of the research, sampling locations were conducted in two regions, namely natural forests and restoration forests located at kilometers $8,10,12,14$ and 16 . The sampling area in each study location was $40 \times 50 \mathrm{~m}^{2}$. Total species of butterflies obtained in the Sebangau National Park Mangkok Resort area of 25 species from four families, namely Papilionidae (8 species), Nymphalidae (11 species), Pieridae (2 species), and Lycaenidae (4 species). Based on the observation and sample obtained, the number of observed individuals was 2,493 butterflies.

Sampling of butterflies using food traps during the dry season in the forest restoration and natural forests is obtained by 16 individuals from 3 species, while in the rainy season the trap that got butterflies only in natural forest is 8 individuals from 2 species. The result of calculation of index of diversity, richness, and evenness of the butterflies in the forest restoration area at each season obtained value of $H^{\prime}=1,952$ which is included in the "low" category, while in dry season has value $\mathrm{H}^{\prime}=2,412$ included into the "medium" category. The evenness index of the butterflies species during the rainy and dry seasons has a value of $E=$ 0.848 and 0.940 which is included in the "almost evenly" category. The richness index of the butterfly in the rainy season and in the dry season has Dmg (R) =1,488 and 2,050 which are in the "low" category. The average value obtained from forest restoration area during rainy season and dry season is 1,975 which belong to the "low" category (Table 1).

The result of calculation of diversity index, richness, and evenness of the butterflies in the natural forest area in each season obtained the value of $H^{\prime}=2,331$ and 2,641 belong to the same category of "medium". The evenness index of the rainy season has a value of $E=$ 0.841 which is included in the "almost evenly" category, while in the dry season the evenness of butterflies species has the value $E=0.975$ included in the "almost evenly" category. The richness index of the butterfly in the dry season and the rainy season has a value of Dmg (R) $=2,145$ and 2,171 belonging to the "low" category. The average value obtained from the 
natural forest area during the rainy season and the dry season is 2,776 , which belongs to the "medium" category (Table 1).

Table 1. Index of diversity, richness, and evenness of the butterflies

\begin{tabular}{ccccccc}
\hline $\begin{array}{c}\text { Habitat / } \\
\text { season }\end{array}$ & $\begin{array}{c}\text { Number } \\
\text { of Family }\end{array}$ & $\begin{array}{c}\text { Number } \\
\text { of species }\end{array}$ & $\begin{array}{c}\text { Number of } \\
\text { individuals }\end{array}$ & H' $^{\prime}$ & Dmg & E \\
NF/D & 4 & 15 & 631 & $\begin{array}{c}4,6 \\
2,\end{array}$ & 2,171 & 0,975 \\
& 4 & 13 & 349 & 12 & 2,050 & 0,940 \\
FR/D & 4 & 16 & 1089 & 31 & 2,145 & 0,841 \\
& 4 & & & 1,9 & & \\
NF/R & 4 & 10 & 424 & 52 & 1,488 & 0,848 \\
\hline
\end{tabular}

Information: NF: Natural Forest; FR: Forest Restoration; D: Dry; R: Rainy; H ': Index of diversity; Dmg (R): The wealth index; $E$ : The evenness index.
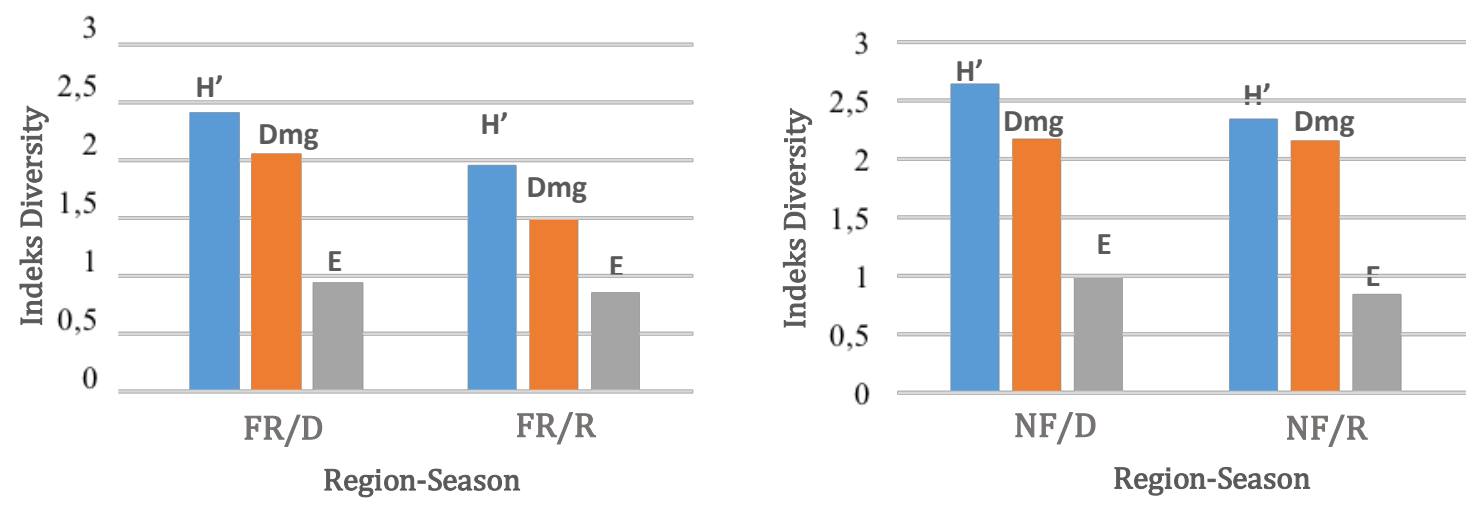

Figure 2. Histogram of Diversity, Richness, and Evenness Butterflies of The Natural Forest Region and The Restoration of Dry Seasion and Rainy Seasion.

The average value obtained from natural forest areas and forest restoration during the dry and rainy seasons is 2.502 . This value shows that the level of diversity, evenness, and species richness fall into the "medium" category.

Table 2. Index of dominance of the butterfly

\begin{tabular}{cc} 
Habitat / season & Dominance index \\
\hline NF/D & 0,00498 \\
NF/R & 0,00918 \\
RF/D & 0,00760 \\
RF/R & 0,01754 \\
\hline
\end{tabular}

Information: NF: Natural Forest; FR: Forest Restoration; D: Dry; R: Rainy; H ': Index of diversity. 
The index values of dominance of the butterflies in the area of the Mangkok resort based on Simpson criteria are low or good $(D<1)$ ranged from $0.00498-0.01754$, and show that the individual abundance of each species in each region of the season seen no dominance phenomenon stand out (Table 2). In line with the dominance index, the relative abundance indexes of the most abundant butterflies' species in this research were found in all regions and in each season by achieving an average percentage of $77.24 \%$ of the Graphium evemon species. The abundance of butterflies species in the second and third positions is occupied by Graphium sarpedon species, and Graphium Agamemnon which reaches an average percentage of $52.86 \%$ and $41.40 \%$. All three species are common species scattered in all areas of the Mangkok resort. The greater number of other species and often found in the forest, indicates a preference that the area has been disturbed by proven loss of forest cover on the riverbank adjacent to the restoration forest area.

Successful vegetation in inventarization at the research sites serving as feed, shelter, and butterflies cover. Vegetation from the Myrtaceae Family is noted more frequently visited by the butterflies of the Papilionidae Family such as Papilio iswara, Graphium Agamemnon, and Graphium evemon. The butterfly of the Nymphalidae Family such as Pandita Sinope, Mycaelesis horsfieldi, and Acraea terpsicore are observed butterflies more frequently visiting plants from the Icacinace and Myrtacinacae Families.

Table 3. Vegetation of feed, shelter, and butterfly cover

\begin{tabular}{|c|c|c|c|c|c|}
\hline Local name & Scientific name & Family & Function & HA & HR \\
\hline Bati-bati & Syzygium zeylainca & Myrtaceae & FSC & $\sqrt{ }$ & $\sqrt{ }$ \\
\hline Manggis hutan/idat & Garcinia sp. & Clusiaceae & FSC & $\sqrt{ }$ & $x$ \\
\hline Butun & Barringtonia sp. & Lecythidaceae & SC & $\sqrt{ }$ & $x$ \\
\hline Jejambu & Eugenia cuprea & Myrtaceae & $\mathrm{F}$ & $\sqrt{ }$ & $\sqrt{ }$ \\
\hline Jamai & Rhodamnia cinerea & Myrtaceae & PSC & $\sqrt{ }$ & $\sqrt{ }$ \\
\hline Luwari & Schima wallichii & Theacea & PSC & $\sqrt{ }$ & $x$ \\
\hline Pansulan & Pternandra coerulescens & Melastomataceae & SC & $\sqrt{ }$ & $x$ \\
\hline Pepagar & Aporosa sp. & Euphorbiaceae & $\mathrm{SC}$ & $\sqrt{ }$ & $x$ \\
\hline Puak & Artocarpus sp. & Moraceae & $\mathrm{FSC}$ & $\sqrt{ }$ & $x$ \\
\hline Semonu & Elaeocorpus microphylum & Elaeocarpaceae & SC & $\sqrt{ }$ & $x$ \\
\hline Ubar & Syzygium sp & Myrtaceae & $\mathrm{F}$ & $\sqrt{ }$ & $\sqrt{ }$ \\
\hline Ubar merah & Syzygium sp & Myrtaceae & $\mathrm{F}$ & $\sqrt{ }$ & $x$ \\
\hline Ubar putih & Syzygium sp & Myrtaceae & $\mathrm{F}$ & $\sqrt{ }$ & $\sqrt{ }$ \\
\hline Ubar samak & Syzygium sp & Myrtaceae & $\mathrm{F}$ & $\sqrt{ }$ & $x$ \\
\hline Nenasi & Syzygium zeylanicum & Myrtaceae & SC & $\sqrt{ }$ & $\sqrt{ }$ \\
\hline Temboras & Memecylon sp & Melastomataceae & FSC & $\sqrt{ }$ & $x$ \\
\hline Kremunting kodok & Melastoma malabathricum & Melastomataceae & $\mathrm{F}$ & $\sqrt{ }$ & $x$ \\
\hline Kremunting padang & Ochtocharis bornensis & Melastomataceae & $\mathrm{S}$ & $\sqrt{ }$ & $x$ \\
\hline Koman & Psychotria viridiflora & Rubiaceae & $\mathrm{S}$ & $\sqrt{ }$ & $x$ \\
\hline Asam keranji & Dialum indum $L$. & Fabaceae & FSC & $\sqrt{ }$ & $x$ \\
\hline Medang kabui & actinodaphne & Lauraceae & FSC & $\sqrt{ }$ & $x$ \\
\hline
\end{tabular}




\begin{tabular}{llllll} 
pasir-pasir & Stenomurus $s p$ & Icacinaceae & SC & $\sqrt{ }$ & $\sqrt{ }$ \\
Asam-asam & Dicryoneura acumonata & Sapindaceae & FSC & $\sqrt{ }$ & $\sqrt{ }$ \\
\hline
\end{tabular}

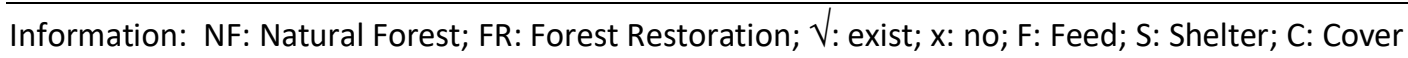

\section{Discussion}

The number of butterfly species found in the Mangkok Resort of Sebangau National Park in the area of restoration forest and natural forest amounted to 25 species belonging to 4 families namely Papilionidae ( 8 species), Nymphalidae (11 species), Pieridae ( 2 species), and Lycaenidae ( 4 species).

Table 4. Presence and number of butterflies in each region for each season

\begin{tabular}{|c|c|c|c|c|c|c|c|}
\hline No & Species & Family & HA & HR & Rainy & Dry & $\begin{array}{l}\text { Number of } \\
\text { individuals }\end{array}$ \\
\hline 1 & Graphium agamemnom & Papilionidae & 146 & 105 & $\sqrt{ }$ & $\sqrt{ }$ & 251 \\
\hline 2 & Graphium sarpedon & Papilionidae & 241 & 108 & $\sqrt{ }$ & $\sqrt{ }$ & 349 \\
\hline 3 & Graphium evemon & Papilionidae & 396 & 149 & $\sqrt{ }$ & $\sqrt{ }$ & 545 \\
\hline 4 & Graphium antipathies & Papilionidae & 23 & 10 & $\sqrt{ }$ & $x$ & 33 \\
\hline 5 & Graphium delesserti & Papilionidae & 32 & 12 & $\sqrt{ }$ & $x$ & 44 \\
\hline 6 & Papilio helenus & Papilionidae & 27 & 52 & $x$ & $\sqrt{ }$ & 79 \\
\hline 7 & Papilio demolion & Papilionidae & 15 & 50 & $x$ & $\sqrt{ }$ & 65 \\
\hline 8 & Chilasa paradoxa & Papilionidae & 40 & 0 & $\mathrm{x}$ & $\sqrt{ }$ & 40 \\
\hline 9 & Euploea mulciber & Nymphalidae & 88 & 0 & $\sqrt{ }$ & $\sqrt{ }$ & 88 \\
\hline 10 & Euploea radamanthus & Nymphalidae & 35 & 0 & $\sqrt{ }$ & $x$ & 35 \\
\hline 11 & Euploea eyndhovii & Nymphalidae & 37 & 0 & $\sqrt{ }$ & $x$ & 37 \\
\hline 12 & Euploea crameri & Nymphalidae & 15 & 9 & $x$ & $\sqrt{ }$ & 24 \\
\hline 13 & Hypolimnas bolina & Nymphalidae & 16 & 0 & $\sqrt{ }$ & $x$ & 16 \\
\hline 14 & Junonia atlites & Nymphalidae & 27 & 40 & $\sqrt{ }$ & $x$ & 67 \\
\hline 15 & Agatasa calydonia & Nymphalidae & 62 & 6 & $x$ & $\sqrt{ }$ & 68 \\
\hline 16 & Pandita sinope & Nymphalidae & 92 & 39 & $x$ & $\sqrt{ }$ & 131 \\
\hline 17 & Melanitis leda & Nymphalidae & 47 & 16 & $x$ & $\sqrt{ }$ & 63 \\
\hline 18 & Acraea violae & Nymphalidae & 38 & 32 & $x$ & $\sqrt{ }$ & 70 \\
\hline 19 & Mycalesis horsfieldi & Nymphalidae & 36 & 8 & $x$ & $\sqrt{ }$ & 44 \\
\hline 20 & Eurema sarilita & Pieridae & 81 & 57 & $\sqrt{ }$ & $\sqrt{ }$ & 138 \\
\hline 21 & Eurema andersoni & Pieridae & 38 & 29 & $\sqrt{ }$ & $x$ & 67 \\
\hline 22 & Arhopala psoudocentaurus & Lycaenidae & 55 & 28 & $x$ & $\sqrt{ }$ & 83 \\
\hline 23 & Celastrina oreas & Lycaenidae & 42 & 8 & $\sqrt{ }$ & $x$ & 50 \\
\hline 24 & Rapala manea & Lycaenidae & 44 & 15 & $\sqrt{ }$ & $x$ & 59 \\
\hline 25 & Caleta roxus & Lycaenidae & 47 & 0 & $x$ & $x$ & 47 \\
\hline & Total & 4 & 1720 & 773 & & & 2493 \\
\hline
\end{tabular}

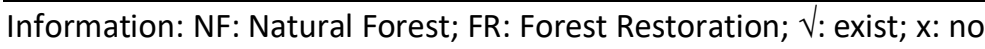

Garcia et al., (2014) suggests that fluctuations in seasonal variation in the availability of fruits during the rainy season and phenological patterns of host plants or in the abundance of 
predators or parasites can lead to changes in species relative abundance and consequently in species. Research Margaret et al., (2014) shows that, the differences in butterfly communities between restoration sites and primary forest is different in each month. Clara et al., (2014) say, in essence, the restored area seems to be going through the process of adding species as the age of restoration increases, the more forest species colonize the older areas. Drumbel et al., (2005) say, the composition of the butterfly community in each season greatly affects the presence in each habitat, and the habitat that is degraded or that is in the regeneration will fluctuate according to the degree of disturbance that occurs. Therefore, restored forests can be important shelters for forest species and increase the permeability of the landscape by allowing fauna mobility between forest patches. As a result, restoration forests could potentially increase regional biodiversity and restore some ecosystems (Clara et al., 2014).

Each family and species of butterfly has its own preference for the plants and sources of feed. This causes the species of butterfly in natural forests to be more diverse because of the varying tree height resulting in canopy cover is also highly variable. Drumbel et al., (2005) reported that selective logging affects vegetation structures and by opening shade areas will produce more homogeneous vegetation structure. Houlihan et al., (2013) states, butterflies have different preferences to direct sunlight. The relation to this case Vu et al., (2011) suggests that the structural complexity of habitat and the diversity of vegetation forms correlates with the diversity of insect species, which in this case are butterflies.

\section{Conclusions}

The level of diversity, evenness and richness of butterfly species in the forest of the restoration during the rainy and dry seasons fall into the "low" category with an average value of the diversity index, the fairness and richness of the butter species of 1.975, while the diversity, fairness and richness of the butterfly species natural forests during the rainy and dry seasons fall into the "medium" category with an average value of diversity index, evenness and richness of the butter species of 2,776 .

\section{Acknowledgments}

The authors would like to thank Sebangau National Park Central Kalimantan for his permission to access the peat swamp forest research station Mangkok Resort, Sebangau, Central Kalimantan, Indonesia. Thanks to academic advisers and friends while in the field.

\section{References}

Borror, D. J., C. A, Triplehorn., \& N. F, Johnson. 1992. Pengenalan pelajaran serangga. Edisi Keenam. Yogyakarta: Gadjah Mada University Press. Terjemahan dari: Introduction to the Study of Insect. Sixth Edition.

Clara, L. B., S, Anna., D. B, Ribeiro., L. C, Garcia., \& A. V. L, Freitas. 2014. Fruit-feeding butterfly communities are influenced by restoration age in tropical forests. Society For Ecological Restoration 1: 1-6.

Drumbell, A.J., \& J. A, Hill. 2005. Impacts of selective logging on canopy and ground assemblages of tropical forest butterflies: Implications for sampling. Biological Conservation 125: 123-131. 
Garcia, L. C., R. J. Hobbs, F. A. M. Santos., and R. R. Rodrigues. 2014. Flower and fruit availability along a forest restoration gradient. Biotropica 46: 114-123.

Harrison, M. E., S. E, Page., \& S. H, Limin. 2009. The global impact of Indonesian forest fires. Biologist 56: $156-163$.

Helvoort, B.V. 1981. Bird Populations in The Rural Ecosistems of West Java. Nature Conservation Depertment. Netrherlands.

Houlihan, P. R., M. E, Harrison., \& S. M, Cheyne. 2013. Impacts of forest gaps on butterfly diversity in a Bornean peat-swamp forest. Journal of Asia-Pacific Entomolgy 16: 67-73.

Margaret, N., V, Anu., N, Philip., \& R, Heikki. 2014. Fruit-feeding communities as indicators of forest restoration in an Afro-tropical rainforest. Biological Conservation 174: 75-83.

Magurran, A. E. 1988. Ecological Diversity and Its Measurement. Chapman and Hall: USA.

Myers, N., R. A, Mittermeier., C. G, Mittermeier., G. A. B, Fonseca., J, Kent. 2000. Biodiversity hotspots for conservation priorities. Nature 403: 853-858.

Odum, E. P. 1971. Fundamentals of Ecology. Toronto: W. B. Saunders Company.

Page, S. E., S, Siegert., J, Rieley., H, Boehm., A, Jaya., \& S. H, Limin. 2002. The amount of carbon released from peat and forest fires in Indonesia during 1997. Nature 420: 61-65.

Patton, R.L. (1963). Introductory Insect Physiology. W.B. Saunders Company, Philadelphia and London. Toppan Company Limited. Tokyo, Japan.

Sodhi, N. S., L.P, Koh., B.W, Brook., P. K. L, Neg. 2004. Southeast Asian biodiversity: an impending disaster. Trends Ecology Evol 19: 654-660.

Terry, T.M. 2000. Microbial taxonomy and evolution. MCB 229. Spring 2000. University of Connecticut. Department of Molecular \& Cell Biology.

Vu. L. V., \& C. Q, Vu. 2011. Diversity pattern of butterfly communities (Lepidoptera, Papilionidae) in different habitat types in a tropical rain forest of Southern Vietnam. International Scholarly Research Network ISRN Zoology 1: 1-8. 